\title{
Batch dissolution of granite and biotite in water: Implication for fluorine geochemistry in groundwater
}

\author{
Gi-TaK Chae, ${ }^{1}$ SeOng-TAeK Yun, ${ }^{1 *}$ Man-Jae Kwon, ${ }^{1}$ Yi-Seop KIM ${ }^{1}$ and Bernhard MaYeR ${ }^{2}$ \\ ${ }^{1}$ Department of Earth and Environmental Sciences and the Environmental Research Laboratory (EGRL), Korea University, \\ Seoul 136-701, Korea \\ ${ }^{2}$ Department of Geology and Geophysics, University of Calgary, Alberta, Canada T2N 1N4
}

(Received May 17, 2004; Accepted July 22, 2005)

\begin{abstract}
We performed batch dissolution experiments on different sized granite and biotite in pure water, in order to better understand the source and geochemical behavior of fluoride in groundwater. Very high concentrations of fluoride (up to 6-10 mg/l) were observed from granite leaching. Correlations between leached ions suggest that fluoride possibly originates from dissolution of biotite. After $\sim 500 \mathrm{hrs}$, fluoride concentration gradually decreased because of the supersaturation with respect to fluorite as a result of the build-up of sufficient $\mathrm{Ca}$ ions by dissolution of Ca-bearing plagioclase. Biotite dissolution experiments also showed that the fluoride concentrations are controlled by the attainment of fluorite saturation, which depends on the removal of $\mathrm{Ca}$ ion by adsorption and/or cation exchange on the surface of clay minerals. In summary, this study indicates that occurrence and behavior of fluorine in groundwater are mainly controlled by fluorite precipitation as a function of $\mathrm{Ca}$ concentration which depends on several geochemical processes such as dissolution of Ca-bearing minerals, calcite precipitation, and adsorption and/or cation exchange.
\end{abstract}

Keywords: fluorine, geochemistry, groundwater, batch dissolution, granite and biotite

\section{INTRODUCTION}

Fluorine $(\mathrm{F})$ is one of the important trace elements for human health, which is obtained mostly by drinking water. Fluorine in natural waters originates dominantly from natural processes and occurs mainly as a free ion $\left(\mathrm{F}^{-}\right)$. A concentration of fluoride less than $0.8 \mathrm{mg} / \mathrm{l}$ in drinking water may result in dental caries, while high concentrations above $1.5 \mathrm{mg} / \mathrm{l}$ may cause an endemic disease called dental fluorosis (Handa, 1975; WHO, 1984; USPHS, 1987; Ripa, 1993). Many peoples in countries such as India, Mexico, Sri Lanka, Kenya, Tanzania, Ghana, China and Spain have been reported to suffer from fluorosis due to intake of fluoride-rich groundwater (Teotia et al., 1981; Dissanayake, 1991; RGNDW, 1993; Grimaldo et al., 1995; Apambire et al., 1997).

Evaluating the causes for elevated fluoride concentrations in natural waters entails the identification of the F source, but also the understanding of solubility, transport and sinks for fluoride ion. Thus, a variety of geochemical studies have been performed on various aspects of fluoride in groundwater. In particular, some researchers have studied the relationship between fluoride concentration and water-rock interaction in various aqui-

*Corresponding author (e-mail: styun@korea.ac.kr)

Copyright $@ 2006$ by The Geochemical Society of Japan. fers with different geologic settings (Nordstrom and Jenne, 1977; Edmunds et al., 1984; Nordstrom et al., 1989; Gaciri and Davies, 1993; Saxena and Ahmed, 2003). Potential sources of fluoride in groundwater include various minerals in rocks and soils, such as fluorite, apatite, amphiboles and micas (Handa, 1975; Pickering, 1985; Wenzel and Blum, 1992; Bardsen et al., 1996; Subba Rao and Devadas, 2003). Fluorite $\left(\mathrm{CaF}_{2}\right)$ has been generally considered as a dominant source of groundwater fluoride, especially in granitic terranes (Deshmukh et al., 1995). However, its solubility in fresh water is low and furthermore its dissolution rate is remarkably slow (Nordstrom and Jenne, 1977). Therefore, some researchers suggested that high fluoride concentrations in groundwater are likely a result of the dissolution of biotite, which may contain significant fluorine at the $\mathrm{OH}^{-}$sites of their octahedral sheet (Nordstrom et al., 1989; Li et al., 2003). However, quantitative assessments of fluoride enrichment in natural waters, especially through the study of fluid-mineral equilibria, are sparse (Saxena and Ahmed, 2001).

In South Korea, excessive fluoride concentrations are frequently encountered in deep groundwater especially in granitic bedrocks, and have emerged as a serious problem in the exploitation and use of groundwater. Therefore, many groundwater wells have been abandoned owing to their excessive fluoride concentration, despite the fact that the standard of fluoride in bottled water is set 
higher in Korea $(2.0 \mathrm{mg} / \mathrm{l})$ than the drinking water standard used in most countries $(1.5 \mathrm{mg} / 1)$. Deep thermal groundwaters in granitic aquifers of South Korea are characterized by very high concentrations of fluoride (median $5.2 \mathrm{mg} / 1$, $\max 22.3 \mathrm{mg} / \mathrm{l}$ ) (Kim, 2001). The fluoride concentration in deep groundwaters in Korea tends to be dependent upon aquifer lithology and well depth (Lee et al., 1997; Kim, 2001); the higher fluoride concentrations are typically observed in deeper wells as well as in granitic and gneissic aquifers, a trend which has been recognized in many studies on groundwaters in granitic setting (White et al., 1963; Yun et al., 1998a). The increase of fluoride concentration toward deeper wells is possibly due to the increase of temperature and residence time with increasing depth, which enhances the dissolution of fluorine-bearing minerals in rocks (Nordstrom et al., 1989; Saxena and Ahmed, 2003).

In spite of such health-related and geologic aspect of fluoride in groundwater, the geochemistry of fluorine in groundwater environments has not been extensively studied in Korea. Therefore, the sources and causes of high fluoride concentrations in groundwater are still controversial. In this study, we performed laboratory experiments on batch dissolution of granite and biotite under different conditions. The objectives were to identify fluoride sources and to understand the relationships between fluoride concentration and degree of water-rock interaction with specific focus on possible solubility controls of fluorine in groundwater. The results of this study will be helpful for developing groundwater wells for safe drinking in granitic terranes.

\section{MeThodS}

For this study, simple batch dissolution experiments were designed to simulate the reaction between groundwater and rock/minerals. After reacting granite and biotite with pure water within small batches for variable reaction times, water compositions were analyzed. Procedures of sample preparation, batch reaction, chemical analysis and data analysis are as below.

\section{Sample preparation}

A fresh granite sample was collected for this study from the Jungwon area, South Korea. This area was chosen because very high fluoride concentrations (up to 14.1 $\mathrm{mg} / \mathrm{l}$ ) were reported for deep groundwaters in the region (Yun et al., 1998b). Bedrock in the Jungwon area consists mainly of Precambrian gneiss and Mesozoic granitoids (biotite granite, porphyritic granite and acidic dikes). According to Kim (1985), the average mineral composition of biotite granite is plagioclase $(38.0 \%)$, quartz (27.4 vol. \%), K-feldspar (26.3\%), biotite $(6.2 \%)$ and muscovite (1.6\%). Locally, granite can be more mafic,
Table 1. Chemical composition of the granite and biotite used for this study, determined by XRF analysis

\begin{tabular}{|c|c|c|}
\hline wt. $\%$ & Whole rock & Biotite \\
\hline $\mathrm{SiO}_{2}$ & 62.08 & 35.79 \\
\hline $\mathrm{Fe}_{2} \mathrm{O}_{3}$ & 4.07 & 20.64 \\
\hline $\mathrm{Al}_{2} \mathrm{O}_{3}$ & 18.24 & 15.34 \\
\hline $\mathrm{TiO}_{2}$ & 0.49 & 2.58 \\
\hline $\mathrm{MnO}$ & 0.08 & 0.24 \\
\hline $\mathrm{CaO}$ & 3.33 & 0.86 \\
\hline $\mathrm{MgO}$ & 0.99 & 3.36 \\
\hline $\mathrm{K}_{2} \mathrm{O}$ & 2.54 & 6.64 \\
\hline $\mathrm{Na}_{2} \mathrm{O}$ & 4.90 & 0.60 \\
\hline $\mathrm{P}_{2} \mathrm{O}_{5}$ & 0.19 & 0.13 \\
\hline $\mathrm{Cl}$ & $<0.01$ & 0.06 \\
\hline $\mathrm{F}$ & 0.29 & 0.37 \\
\hline Total & 97.21 & 86.61 \\
\hline
\end{tabular}

containing a larger amount of biotite. Our sample contained $14.7 \mathrm{wt}$. \% of biotite, according to the calculation of mineral modes based on X-ray fluorescence (XRF) data (Table 1). The estimated mode for anorthite (An) in the sample was $16.5 \%$. The fluorine content of the sample was 0.29 wt. \% (Table 1). The sample was crushed and powdered with ceramic ball mills and was then separated into three size fractions using nylon sieves: fraction $\mathrm{A}$ $(<63 \mu \mathrm{m})$, fraction $\mathrm{B}(125$ to $180 \mu \mathrm{m})$, and fraction $\mathrm{C}$ (250 to $600 \mu \mathrm{m}$ ).

In addition to whole-rock samples, biotite was prepared for batch dissolution experiments. Biotite was separated from crushed biotite granite by magnetic separation and hand-picking and was then powdered with a ceramic ball mill. The powdered biotite was examined for purity by X-ray diffraction (XRD) and was finally sieved into the same fractions as whole-rock samples. Chemical data obtained by XRF analysis showed that the prepared biotite samples had a fluorine content of on average 0.37 wt. \% (Table 1). The chemical formula of the biotite was $\left(\mathrm{K}_{1.4} \mathrm{Na}_{0.2} \mathrm{Ca}_{0.2}\right)_{1.8}\left(\mathrm{Mg}_{0.8} \mathrm{Mn}_{0.03} \mathrm{Fe}_{2.6} \mathrm{Ti}_{0.3} \mathrm{Al}_{1}\right)_{5.1}\left(\mathrm{Si}_{6} \mathrm{Al}_{2}\right)_{8} \mathrm{O}_{24}$ $\left(\mathrm{OH}_{1.8} \mathrm{~F}_{0.4} \mathrm{Cl}_{0.03}\right)_{2.2}$ according to calculations performed with MINPET 2.02 software of Geological Software Inc., Canada.

\section{Batch dissolution experiment, chemical analysis, and data analysis}

Simple batch reaction experiments were performed for whole-rock granite samples and pure biotite samples. They were reacted with ultra-pure water $(\mathrm{pH} 7.0)$ within tightly capped high-density polyethylene vials $(50 \mathrm{~mL})$ at a constant temperature of $25^{\circ} \mathrm{C}$ in a thermostat. The vials were laterally shaken $(200 \mathrm{rpm})$ in order to homogenize the samples and to facilitate water-to-rock (or mineral) reactions. All batches were designed to have a con- 
stant water-to-rock (or mineral) ratio $(5: 1)$, but variable size fractions (fraction $\mathrm{A}, \mathrm{B}$, and $\mathrm{C}$; see above) and reaction times (500-1,200 hrs). Maximum reaction times were 1,200 and 500 hrs respectively for the powered granite and biotite.

In order to maintain a closed system condition with respect to air, each reaction vial was kept closed before the solution sampling after the desired time. Sampling of the solution (about $50 \mathrm{~mL}$ ) from reaction vials was undertaken after 5, 24, 48, 90, 144, 300, 500 and 1,200 hrs for granite dissolution experiments and 5, 10, 24, 48, 72, 100, 200, 300 and $500 \mathrm{hrs}$ for biotite dissolution experiments. Because the granite and biotite dissolution experiments were both performed for three size fractions, total numbers of sampled solution were 24 for granite dissolution and 27 for biotite dissolution. The residue in the vial after solution sampling was not used again for further experiments. The obtained solution within each vial was measured for $\mathrm{pH}$ using a combined glass/reference micro-electrode after calibration with $\mathrm{pH} 4.01,7.00$, and 10.01 buffers. The solution was filtered through $0.45 \mu \mathrm{m}$ membrane filters and was then analyzed for cations and anions by inductively coupled plasma-mass spectrometry (ICP-AES; Perkin-Elmer OPTIMA 3000) and ion chromatography (IC; Dionex DX-120), respectively. Bicarbonate content was measured using an acid titration technique. The accuracy of the analytical procedure was evaluated by checking the sample containers for background concentration by preparing blank samples as well as using duplicate or triplicate sub-samples and standard materials (NIST 2694a Simulated Rainwater and Perkin Elmer Pure Atomic Spectroscopy Standards).

Regression analysis was performed in order to assess whether there were significant correlations among the ionic concentrations obtained. Thermodynamic considerations of the solution chemistry were performed using the computer program PHREEQC (Parkhurst and Appello, 1999).

\section{RESULTS AND DISCUSSION}

\section{Granite dissolution}

The results of the dissolution of granite samples are shown in Fig. 1 as the changes of ionic concentrations with time. In the beginning stage (about $<150 \mathrm{hrs}$ ) of the reaction, the concentrations of most ions including fluoride increased significantly. This indicates that the rate of granite dissolution was very fast during this period, possibly because many dislocations (defects) in the surfaces of constituent minerals were produced during the sample preparation procedure (especially crushing), hence facilitating mineral dissolution (Drever, 1997). The finest size fraction showed the highest concentrations of leached cations (Fig. 1) because the smaller grain size
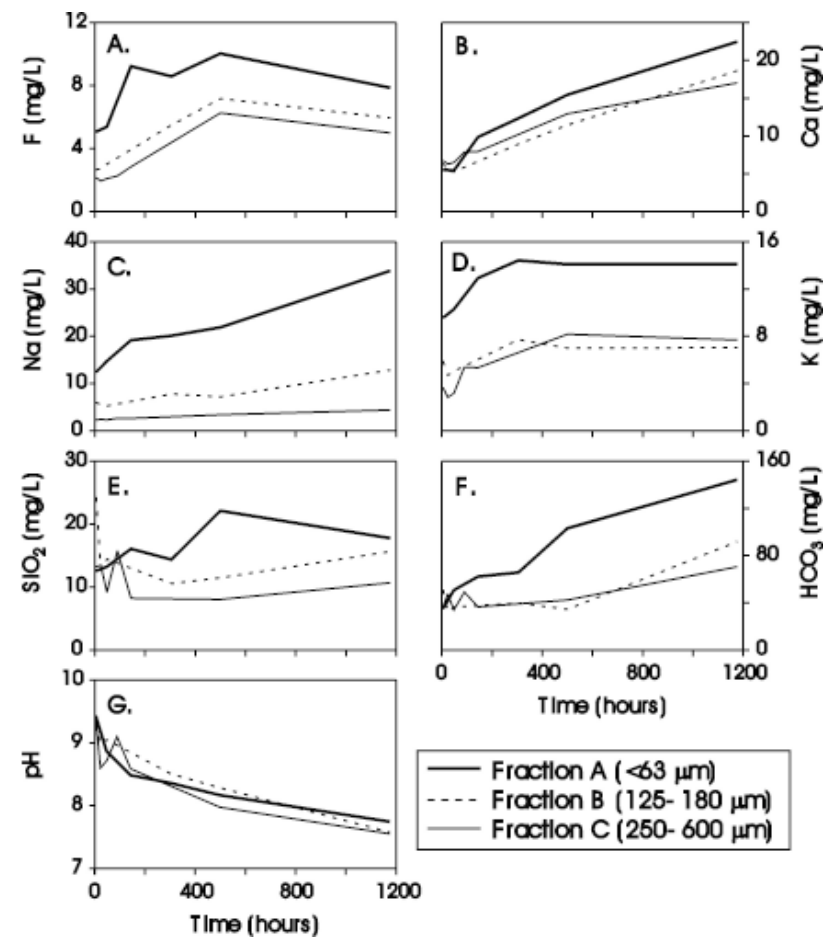

Fig. 1. Time-series variations of the concentrations of leached $F$ (in A), Ca (in B), Na (in C), K (in D), silica (in E) and bicarbonate (in $F$ ) and of $\mathrm{pH}$ (in $G$ ) in granite dissolution. The grain size was $<63 \mu \mathrm{m}$ for fraction $A, 125$ to $180 \mu \mathrm{m}$ for fraction $B$, and 250 to $600 \mu \mathrm{m}$ for fraction $C$.

results in a larger surface area to facilitate the dissolution rate of constituent minerals. Fluoride concentrations in experiments with granite of the finest size fraction (fraction A) approached a maximum value of about $10 \mathrm{mg} / \mathrm{l}$ (Fig. 1A).

The correlation coefficients ( $\mathrm{r}$ ) between leached fluoride and other constituents are summarized in Table 2A. Regardless of the size fraction, fluoride commonly showed a good correlation with $\mathrm{K}, \mathrm{Na}$ and $\mathrm{Ca}$. These inter-cationic correlations indicate that the chemical composition of the leached solution changed mainly as a result of progressive dissolution of silicate minerals such as plagioclase and biotite. The excellent correlation between fluoride and potassium $(r=0.92)$ suggests that these two ions originated from the same mineral, most likely biotite.

With increasing reaction time, concentrations of silica, fluoride and some cations except potassium increased continuously as a result of water-granite interaction (Fig. 1). Calcium and sodium concentrations increased gradually with time (Figs. $1 \mathrm{~B}$ and $\mathrm{C}$ ), suggesting that both ions were supplied continuously by the dissolution of plagioclase. Potassium concentrations initially increased and then remained constant after about 300-500 hrs 

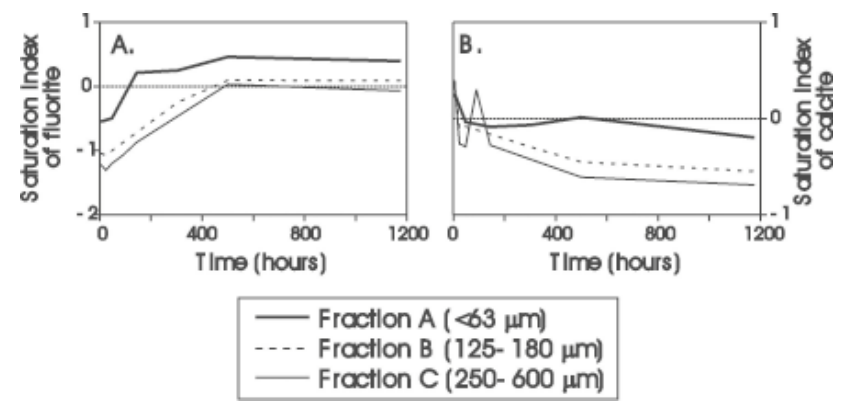

Fig. 2. Time-series variation of the calculated saturation indices (S.I.) of fluorite (in A) and calcite (in B) in leached solution during granite dissolution. The size range of each fraction is the same as in Fig. 1.

(Fig. 1D), suggesting the dissolution of biotite to supply $\mathrm{K}$ ions within the reaction time. Silica concentrations varied between about 10 and $20 \mathrm{mg} / \mathrm{l}$ as a result of dissolution of silicates (Fig. 1E), reflecting the low stability of amorphous silica (as a control of the silica concentration) in water (Appelo and Postma, 1993). Bicarbonate showed a trend of increased concentration with time (Fig. $1 \mathrm{~F})$, indicating that dissolution of silicate minerals proceeded gradually. The solution $\mathrm{pH}$ increased rapidly to about 9.5 in the beginning stage of experiments due to the consumption of hydrogen ion for dissolution of silicate minerals, and then decreased slightly and gradually and remained around 8 (Fig. 1G).

Interestingly, the fluoride concentration increased initially and then decreased after about 500 hrs (Fig. 1A). For this observation, we consider the role of fluorite precipitation in solution. The calcium concentration increased continuously within reaction time (Fig. 1B), due to continuous dissolution of Ca-bearing plagioclase. Calculation of saturation index (S.I.) showed that the solution approached a saturated or supersaturated state (S.I. $\geq 0$ ) with respect to fluorite $\left(\mathrm{K}_{\mathrm{sp}}=10^{-10.6}\right.$; Ball and Nordstrom, 1991) after less than $200 \mathrm{hrs}$ for the size fraction $\mathrm{A}$, and at 450-500 hrs for the size fractions B and C (Fig. 2A). Calcite saturation $\left(\mathrm{K}_{\mathrm{sp}}=10^{-8.48}\right.$; Ball and Nordstrom, 1991) was not reached during the reaction time (Fig. 2B). Therefore, we suggest that fluorite precipitation occurred in the latter part of the experiments and controlled the fluoride concentration in the solution. To induce fluorite precipitation, fluorine and calcium were likely supplied from dissolution of biotite and Ca-bearing plagioclase, respectively.

However, the fluoride concentration could not increase continuously but rather decreased when fluorite started to precipitate in solution after a certain time elapsed, probably because biotite in granite dissolved to supply fluoride in a restricted time range of 300-500 hrs (as suggested by the change of $\mathrm{K}$ ion concentration), while $\mathrm{Ca}$
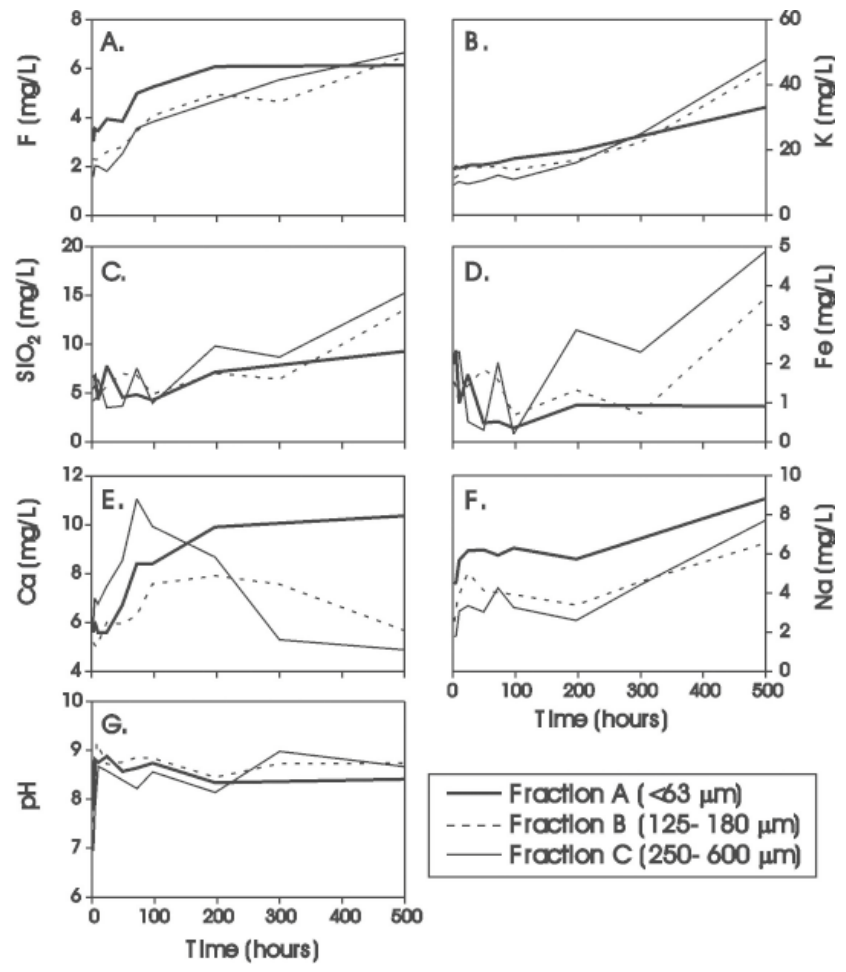

Fig. 3. Time-series variations of the concentrations of leached $F$ (in A), $K$ (in B), silica (in C), Fe (in D), Ca (in E) and Na (in $F$ ) and of $\mathrm{pH}$ (in $G$ ) in biotite dissolution. The grain size was $<63 \mu \mathrm{m}$ for fraction A, 125 to $180 \mu \mathrm{m}$ for fraction $B$, and 250 to $600 \mu \mathrm{m}$ for fraction $C$.

ion was continuously and abundantly supplied from Cabearing plagioclase. Therefore, fluoride concentration is likely controlled by the degree of biotite dissolution as well as the fluorite precipitation.

\section{Biotite dissolution}

Results of the dissolution of biotite samples are shown in Fig. 3. Based on the inter-ionic correlations between fluoride and other leached ions, fluoride showed the best correlation with $\mathrm{K}(\mathrm{r}=0.81$; Table 2B). This trend, which was also observed for the granite dissolution experiments (Table 2A), indicates that fluoride probably originated from dissolving biotite.

With increasing reaction time, the concentrations of $\mathrm{F}, \mathrm{K}$ and silica which form the constituents of biotite increased gradually. The fraction A sample $(<63 \mu \mathrm{m})$ generally showed the highest concentration of fluoride ion (Fig. 3A), due to its large surface area and hence high reactivity. The increase of fluoride concentration in fraction A was negligible after about $200 \mathrm{hrs}$, however (Fig. 3A). After 100-300 hrs, the concentrations of K and silica in experiments with fraction A were lower than those from coarser fractions $\mathrm{B}$ and $\mathrm{C}$ (Figs. 3B and C). Interestingly, leached $\mathrm{Fe}$ in experiments with fraction A biotite 
Table 2. Correlation coefficients $(r)$ between concentrations of leached ions during granite and biotite dissolution, together with its significant level $(p)$ in parenthesis

\begin{tabular}{lcccr}
\hline & $\mathrm{F}-\mathrm{Ca}$ & $\mathrm{F}-\mathrm{Na}$ & $\mathrm{F}-\mathrm{K}$ & $\mathrm{F}^{-\mathrm{SiO}_{2}}$ \\
\hline A. Granite dissolution & & & & \\
fraction A $(<63 \mu \mathrm{m})$ & $0.59(0.11)$ & $0.49(0.16)$ & $0.88(0.01)$ & $0.81(0.03)$ \\
fraction B $(125-180 \mu \mathrm{m})$ & $0.74(0.05)$ & $0.61(0.10)$ & $0.83(0.02)$ & $-0.51(0.15)$ \\
fraction C $(250-600 \mu \mathrm{m})$ & $0.87(0.01)$ & $0.81(0.01)$ & $0.93(0.00)$ & $-0.54(0.10)$ \\
Total & $0.63(0.00)$ & $0.79(0.00)$ & $0.92(0.00)$ & $0.26(0.14)$ \\
B. Biotite dissolution & & & & \\
fraction A $(<63 \mu \mathrm{m})$ & $0.97(0.00)$ & $0.69(0.02)$ & $0.75(0.01)$ & $0.33(0.19)$ \\
fraction B $(125-180 \mu \mathrm{m})$ & $0.46(0.10)$ & $0.62(0.04)$ & $0.85(0.00)$ & $0.81(0.00)$ \\
fraction C $(250-600 \mu \mathrm{m})$ & $0.20(0.29)$ & $0.79(0.00)$ & $0.86(0.00)$ & $0.83(0.00)$ \\
Total & $0.24(0.10)$ & $0.73(0.00)$ & $0.81(0.00)$ & $0.66(0.00)$ \\
\hline
\end{tabular}

also decreased quickly (Fig. 3D). We suggest that such trends observed in the fraction A solution resulted from the formation of amorphous Fe-hydroxides; in fact, the surfaces of biotites in faction A showed a strong brown orange shade with the naked eye after about 200 hrs, suggesting secondary Fe-hydroxide coatings. These coatings possibly inhibit or retard the further dissolution of biotite due to the "protective coating" effects (Velbel, 1993; Murakami et al., 1998). This may explain the constant fluoride concentrations below about $6 \mathrm{mg} / \mathrm{l}$ after about $200 \mathrm{hrs}$ in the faction A experiments (Fig. 3A).

$\mathrm{Ca}$ and $\mathrm{Na}$ are minor constituents in biotite. $\mathrm{Ca}$ and $\mathrm{Na}$ concentrations in the solutions are shown in Figs. 3E and F. Calcium concentrations in experiments with fraction A biotite increased initially and remained constant after 200 hrs. In contrast, Ca concentrations decreased in the second part of experiments with biotite size fractions $\mathrm{C}$ and $\mathrm{B}$. Calculation of saturation index indicates that fluorite reached saturation only in the fraction A solution after about 100 hrs (Fig. 4). Such saturation state in the fraction A likely resulted in concentrations of $\mathrm{Ca}$ below about $10 \mathrm{mg} / \mathrm{l}$ and $\mathrm{F}$ below about $6 \mathrm{mg} / \mathrm{l}$ in the latter part of the experiment, as shown in Fig. 3. On the other hand, fluoride concentrations in experiments with fractions $\mathrm{B}$ and $\mathrm{C}$ increased gradually throughout the observation period, which suggested that these two solutions were undersaturated with respect to fluorite (Fig. 4). Here, we should explain the reason for the Ca decrease in the fractions $\mathrm{B}$ and $\mathrm{C}$. The role of calcite precipitation could be ruled out because calcite $\left(\mathrm{K}_{\mathrm{sp}}=10^{-8.48}\right)$ could not precipitate prior to fluorite $\left(\mathrm{K}_{\mathrm{sp}}=10^{-10.6}\right)$ owing to its higher solubility. Furthermore, the calculated saturation index of calcite was always below zero, indicating an undersaturation of the solution with respect to calcite. Thus, we consider the role of cation exchange or adsorption for Ca removal.

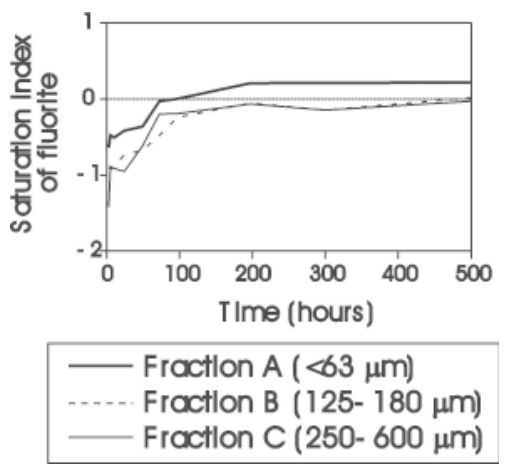

Fig. 4. Time-series variation of the calculated saturation indices (S.I.) of fluorite in leached solution during biotite dissolution. The size range of each fraction is the same as in Fig. 3.

Because Fe-hydroxide precipitates possibly could not form in the fractions $\mathrm{B}$ and $\mathrm{C}$ within the examined time, the surface of biotites in these solutions could have dissolved to weather to clay minerals. The clay minerals could remove $\mathrm{Ca}$ ions by adsorption and/or cation exchange, because their surfaces could be negatively charged under alkaline ( $\mathrm{pH}=8$ to 9 ; Fig. 3G) solution. On the other hand, the biotite surface in the fraction A was partly coated by $\mathrm{Fe}$-hydroxides in the latter part of the experiment, which might have resulted in a retardation of biotite dissolution (as reflected by the sluggish increase of $\mathrm{SiO}_{2}, \mathrm{~K}$ and $\mathrm{Na}$ ). The Fe-hydroxides probably had near-neutral surface charge in alkaline solution, because its PZC (point of zero charge) values are around 8.5 (Stumm and Morgan, 1996). Thus, biotite grains in experiments with biotite of size fraction A did not have the ability to remove $\mathrm{Ca}$ ion by adsorption and/or cation exchange. As a result, the fraction A solution could maintain an equilibrium state with respect to fluorite. Thus, 
we consider that fluorite precipitation only acted to control the concentrations of $\mathrm{Ca}$ and $\mathrm{F}$.

Summary and discussion of the experimental results: implication for fluoride in groundwater in South Korea

In the early period of granite dissolution, fluoride concentration in leached water exceeded the Korean Drinking Water Standard $(1.5 \mathrm{mg} / \mathrm{l})$ just upon the start of dissolution and then gradually increased up to about 6-10 $\mathrm{mg} / \mathrm{l}$. A good correlation between fluoride and potassium ion concentrations indicated that fluoride is likely originated from dissolution of fluorine-bearing biotite in granite. In the second part of the experiments (after about 500 hrs), however, fluoride concentration decreased gradually. This phenomenon was a result of the process called "geochemical divide"; the successive precipitation of fluorite $\left(\mathrm{CaF}_{2}\right)$ in solution occurred due to the supply of sufficient amount of calcium ions from dissolving $\mathrm{Ca}$ bearing plagioclase and resulted in increased $\mathrm{Ca}$ but decreased F concentrations. Therefore, our present data indicate that fluoride ion concentration in groundwater is controlled by the precipitation of fluorite as a function of $\mathrm{Ca}$ concentration in water. Our data also successfully explains the general observations that high fluoride concentrations in a specific region are associated with relatively Ca-poor groundwater.

In the biotite dissolution, fluoride concentration reached up to about $6 \mathrm{mg} / \mathrm{l}$ within $500 \mathrm{hrs}$. However, the increasing rate of fluoride concentration, as well as its absolute concentration, was variable with the size of biotite as follow: (1) the fluoride leached from finer-sized biotite $(<63 \mu \mathrm{m})$ increased up to about $6 \mathrm{mg} / \mathrm{l}$ after about $200 \mathrm{hrs}$ but then was constant, and (2) the fluoride leached from coarser-sized biotites (125-180 and 250-600 $\mu \mathrm{m}$ ) progressively increased within the reaction time. The change of dissolved $\mathrm{Fe}$, as well as the observation showing the formation of brownish yellow precipitates, indicates that Fe-hydroxides formed during the dissolution of finer-sized biotite. These Fe-hydroxides partly coated the surface of biotite and thus acted to retard the biotite dissolution with increasing reaction time. As a result, the formation of secondary clay minerals on biotite surfaces was possibly inhibited and therefore the leached $\mathrm{Ca}$ ion could not be effectively removed from solution by adsorption or cation exchange. Ultimately in the solution with finer-sized biotite, increased $\mathrm{Ca}$ ion possibly formed a saturation state with respect to fluorite. The fluoride concentration therefore remained constant. On the other hand, the surfaces of coarser-grained biotites were dissolved continuously without the formation of Fe-hydroxides and could be converted to clay minerals. Thus, leached $\mathrm{Ca}$ ions could be removed by adsorption and/or cation exchange on the surface of clay minerals. Such depletion of $\mathrm{Ca}$ ions played an important role to maintain

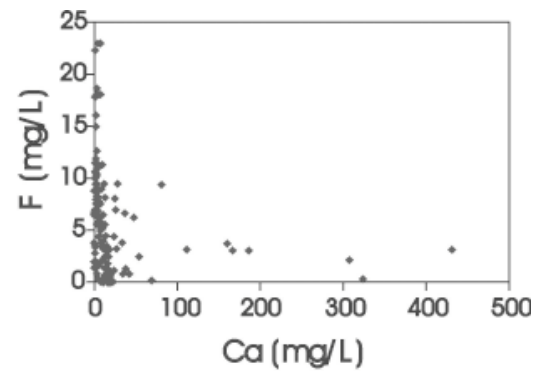

Fig. 5. The relationship between $C a$ and $F$ concentrations in deep groundwaters $(n=149)$ in granitic rocks in South Korea.

the undersaturation state with respect to fluorite; therefore, the fluoride concentration could increase continuously within the reaction time.

Our results on fluorine geochemistry also agree well with the field observations by Handa (1975) and those of many other researchers; the importance of fluorite precipitation has been suggested for areas where high fluoride concentrations have been observed in relatively $\mathrm{Ca}$ poor groundwaters (Kilham and Heckey, 1973; Nanyaro et al., 1984; Gaciri and Davies, 1993; Kundu et al., 2001; Sujatha, 2003). Compared with $\mathrm{Na}-\mathrm{HCO}_{3}$ type groundwater, $\mathrm{Ca}-\mathrm{HCO}_{3}$ type groundwater is known to generally contain lower fluoride (Lee et al., 1997). Its hydrochemistry is characterized by increased $\mathrm{Ca}$ ion concentration with increasing TDS (total dissolved solid) due to the gradual dissolution of carbonate minerals and $\mathrm{Ca}$ bearing plagioclase in aquifer materials (Yun et al., 1998a, b; Kim, 2001; Sujatha, 2003). The $\mathrm{Na}-\mathrm{HCO}_{3}$ type groundwaters are generally enriched in fluoride and sodium ions, due to the dissolution of silicates as well as the removal of $\mathrm{Ca}^{2+}$ by calcite precipitation and cation exchange (Chae et al., 2005; Kim and Yun, 2005). Based on the results of this study, it can therefore be expected that deep groundwater with higher natural concentration of $\mathrm{Ca}$ ion would contain less fluoride than waters with lower $\mathrm{Ca}$, probably as a result of different degrees of saturation with respect to fluorite.

Deep thermal groundwaters in granitic bedrocks of South Korea are classified into two chemical types (Yun et al., 1998a, b; Kim, 2001): $\mathrm{Ca}(-\mathrm{Na})-\mathrm{HCO}_{3}$ type and $\mathrm{Na}-$ $\mathrm{HCO}_{3}$ type. The $\mathrm{Na}-\mathrm{HCO}_{3}$ type groundwaters tend to be enriched in fluoride and sodium ions, due to the dissolution of silicates as well as the removal of $\mathrm{Ca}^{2+}$ by calcite precipitation and cation exchange (Chae et al., 2005). Thus, high fluorine concentration in groundwater in South Korea is usually associated with low Ca levels. In addition, the $\mathrm{Na}-\mathrm{HCO}_{3}$ type groundwaters with higher $\mathrm{F}$ concentration have higher $\mathrm{Na}$ and silica concentrations, indicating that a larger degree of silicate mineral dissolution in aquifers during their deep and long circulation is 
related to higher $\mathrm{F}$ concentrations. Deep groundwaters with higher natural $\mathrm{Ca}$ ion concentrations are expected to contain less fluoride than waters with lower $\mathrm{Ca}$, as a result of different degrees of saturation with respect to fluorite. To examine the relationship between $\mathrm{Ca}$ and $\mathrm{F}$ concentrations, we collected a total of 149 hydrochemical data of deep groundwaters in granitic bedrocks in South Korea (Fig. 5). The result shows that groundwaters with higher $\mathrm{Ca}$ concentrations $(>50 \mathrm{mg} / \mathrm{L})$ are low in $\mathrm{F}$ concentration $(<5 \mathrm{mg} / \mathrm{L})$, while groundwaters with lower $\mathrm{Ca}$ contents belong to the $\mathrm{Ca}(-\mathrm{Na})-\mathrm{HCO}_{3}$ type and are typically enriched in $\mathrm{F}$ (up to about $23 \mathrm{mg} / \mathrm{L}$ ). This trend agrees with our experimental results which showed that the concentrations of leached $\mathrm{F}$ during granite dissolution decreased with higher $\mathrm{Ca}$ concentrations (Figs. 1A and B).

\section{CONCLUSION}

In order to understand the source and behavior of fluorine in groundwater in granitic bedrocks, we performed batch dissolution experiments of differently sized (i.e., in the order of coarsening, fractions A, B and C), granite and biotite in pure water for 500-1,200 hrs under a constant water-to-rock (or mineral) ratio (5:1). The experiments on granite dissolution showed that the concentration of fluoride in solution decreased after about $500 \mathrm{hrs}$, regardless of grain size, likely due to the attainment to saturation or supersaturation with respect to fluorite as a result of $\mathrm{Ca}$ supply from dissolving $\mathrm{Ca}$-bearing plagioclase. Biotite dissolution experiments showed two contrasting trends with respect to fluoride concentration in solution: (1) fluoride concentration in the fraction $\mathrm{A}$ solution remained constant after about $200 \mathrm{hrs}$, likely due to fluorite precipitation by the continuous supply of $\mathrm{Ca}$ ions; (2) fluoride concentration in experiments with biotite fractions $\mathrm{B}$ and $\mathrm{C}$ progressively increased, because fluorite could not precipitate possibly as a result of $\mathrm{Ca}$ ion removal in solution by adsorption onto and/or cation exchange with secondary clay minerals. Therefore, the results of our granite and biotite dissolution experiments indicate that the geochemical behavior and concentration of fluorine in groundwater are controlled not only by the existence of $\mathrm{Ca}$-bearing minerals ( $\mathrm{Ca}$-bearing plagioclase and carbonates) in rocks but also by the fluorite precipitation as a function of the absolute concentration and behavior (removal) of calcium ions in water. Our results may also explain the general observation that high fluoride concentration in a specific region is usually associated with $\mathrm{Ca}$-poor and $\mathrm{Na}$-rich groundwater.

This study suggests that (1) fluoride in groundwater in granitic bedrocks may effectively originate from dissolution of biotite, (2) the concentration of fluoride is largely controlled by the degree of saturation of water with respect to fluorite, which depends on $\mathrm{Ca}$ ion concentration, and (3) preferential removal of $\mathrm{Ca}$ ions by several geochemical processes in aquifers, such as calcite precipitation, adsorption and cation exchange, may generate high concentrations of fluoride in groundwater. The results of this study will be effectively used to develop groundwater wells for supplying safe drinking water with appropriate fluoride concentrations and also to propose efficient remedial measures for fluoride-rich waters.

Acknowledgments - This work was supported by a grant (041C00288) from Korea Research Foundation. Field works and chemical analysis were partly supported by the Environmental Geosphere Research Lab (EGRL) of Korea University. This paper has been much improved because of the comments from Dr. Tasuku Akagi (Journal Editor), Dr. Yves Godderis and an anonymous journal reviewer.

\section{REFERENCES}

Apambire, W. M., Boyle, D. R. and Michel, F. A. (1997) Geochemistry, genesis, and health implications of fluoriferous groundwaters in the upper regions of Ghana. Environ. Geol. 35, 13-24.

Appelo, C. A. J. and Postma, D. (1993) Geochemistry, Groundwater and Pollution. Rotterdam, Balkema.

Ball, J. W. and Nordstrom, D. K. (1991) WATEQ4F-User's manual with revised thermodynamic data base and test cases for calculating speciation of major, trace and redox elements in natural waters. US Geological Survey Open-File Report 90-129.

Bardsen, A., Bgorraton, K. and Selving, K. A. (1996) Variability in fluoride content of sub-surface water reservoir. Acta Odontol. Scand. 54, 343-347.

Chae, G. T., Yun, S. T., Kim, K. and Mayer, B. (2005) Hydrogeochemistry of sodium-bicarbonate type bedrock groundwater in the Pocheon spa area, South Korea: waterrock interaction and hydrologic mixing. J. Hydrol., doi:10.1016/j.jhydrol.2005.08.006.

Deshmukh, A. N. (1995) Valadaskar PM, Malpe DB. Fluoride in environment: a review. Gondwana Geol. Mag. 9, 1-20.

Dissanayake, C. B. (1991) The fluoride problem in the groundwater of Sri Lanka-environmental management and health. Int. J. Environ. Studies 38, 137-156.

Drever, J. I. (1997) The Geochemistry of Natural Waters: Surface and Groundwater Environments (3rd ed.). Upper Saddle River, New Jersey, Prentice Hall, 220-221.

Edmunds, W. M., Andrews, J. N., Burgess, W. G., Kay, R. L. F. and Lee, D. J. (1984) The evolution of saline and thermal groundwaters in the Carnmenellis granite. Miner. Mag. 48, 407-424.

Gaciri, S. J. and Davies, T. C. (1993) The occurrence and geochemistry of fluoride in some natural waters of Kenya. J. Hydrol. 143, 395-412.

Grimaldo, M., Borja-Aburto, V. H., Ramírez, A. L., Ponce, M., Rosas, M. and Diaz-Barriga, F. (1995) Endemic fluorosis in San Luis Potosí, Mexico. Environ. Res. 68, 25-30. 
Handa, B. K. (1975) Geochemistry and genesis of fluoride containing groundwater in India. Ground Water 13, 275-281.

Kilham, P. and Heckey, R. E. (1973) Fluoride geochemical and ecological significance in East African waters and sediments. Limnol. Oceanogr. 16, 932-945.

Kim, D. R. (1985) A study on genesis of the Daewha tungstenmolybdenum deposits. Unpub. Ms. thesis, Seoul Nat'l Univ. (in Korean).

Kim, K. and Yun, S. T. (2005) Buffering of sodium concentration by cation exchange in the groundwater system of a sandy aquifer. Geochem. J. 39, 273-284.

Kim, S. Y. (2001) Hydrogeochemical, geostatistical and thermodynamical studies on deep thermal groundwater, Korea. Unpub. Ph.D thesis, Korea Univ.

Kundu, N., Panigrahi, M. K., Tripathy, S., Munshi, S., Powell, M. A. and Hart, B. R. (2001) Geochemical appraisal of fluoride contamination of groundwater in the Nayagarh district of Orissa, India. Environ. Geol. 41, 451-460.

Lee, J. U., Chon, H. T. and John, Y. W. (1997) Geochemical characteristics of deep granitic groundwater in Korea. $J$. Kor. Soc. Groundwater Environ. 4, 199-211 (in Korean).

Li, Z., Tainosho, Y., Shiraishi, K. and Owada, M. (2003) Chemical characteristics of fluorine-bearing biotite of early Paleozoic plutonic rocks from the Sor Rondane Mountains, East Antarctica. Geochem. J. 37, 145-161.

Murakami, T., Kogure, T., Kadohara, H. and Ohnuki, T. (1998) Formation of secondary minerals and its effect on anorthite dissolution. Am. Mineral. 83, 1209-1219.

Nanyaro, J. T., Aswathanarayana, U., Mungore, J. S. and Lahermo, P. W. (1984) A geochemical model for the abnormal fluoride concentrations in waters in parts of northern Tanzania. J. Afr. Earth Sci. 2, 129-140.

Nordstrom, D. K. and Jenne, E. A. (1977) Fluoride solubility in selected geothermal waters. Geochim. Cosmochim. Acta 41, 175-188.

Nordstrom, D. K., Ball, J. W., Donahoe, R. J. and Whittemore, D. (1989) Groundwater chemistry and water-rock interactions at Stripa. Geochim. Cosmochim. Acta 53, 1727-1740.

Parkhurst, D. L. and Appelo, C. A. J. (1999) User's guide to PHREEQC (version 2) - a computer program for speciation, batch-reaction, one-dimensional transport, and inverse geochemical calculations. US Geol. Surv. Water-Resour. Invest. Rep. 99-4259.

Pickering, W. F. (1985) The mobility of soluble fluoride in soils. Environ. Poll. 9, 281-308.

RGNDW (Rajiv Gandhi National Drinking Water Mission) (1993) Prevention and Control of Fluorosis in India. Tech- nical Report, New Delhi.

Ripa, L. W. (1993) A half-century of community water fluoridation in the United States: review and commentary. J. Public Health Dent. 53, 17-44.

Saxena, V. K. and Ahmed, S. (2001) Dissolution of fluoride in groundwater: a water-rock interaction study. Environ. Geol. 40, 1084-1087.

Saxena, V. K. and Ahmed, S. (2003) Inferring the chemical parameters for the dissolution of fluoride in groundwater. Environ. Geol. 43, 731-736.

Stumm, W. and Morgan, J. J. (1996) Aquatic Chemistry-Chemical Equilibrium and Rates in Natural Waters (3rd ed.). Wiley, New York.

Subba Rao, N. and Devadas, D. J. (2003) Fluoride incidence in groundwater in a area of Peninsula India. Environ. Geol. 45, 243-251.

Sujatha, D. (2003) Fluoride levels in the groundwater of the south-eastern part of Ranga Reddy district, Andhra Pradesh, India. Environ. Geol. 44, 587-591.

Teotia, S. D. S., Teotia, M. and Singh, R. K. (1981) Hydrogeochemical aspects of endemic skeletal fluorosis in India-an epidemiological study. Fluoride 14, 69-74.

USPHS (United States Public Health Services) (1987) Drinking Water Standards. Public Health Services Pub., Washington, D.C.

Velbel, M. A. (1993) Formation of protective surface layers during silicate-mineral weathering under well-leached, oxidising conditions. Am. Mineral. 78, 405-414.

Wenzel, W. W. and Blum, W. E. H. (1992) Fluoride speciation and mobility in fluoride contaminated soil and minerals. Soil Sci. 153, 357-364.

White, D. E., Hem, J. D. and Warming, G. A. (1963) Chemical composition of subsurface water. US Geol. Surv. Prof. Pap. 440-F.

WHO (World Health Organization) (1984) Guidelines for Drinking Water Quality, Vol. 3. Drinking Water Quality Control in Small Community Supplies. Geneva.

Yun, S. T., Chae, G. T., Koh, Y. K., Kim, S. R., Choi, B. Y., Lee, B. H. and Kim, S. Y. (1998a) Hydrogeochemical and environmental isotope study of groundwaters in the Pungki area. J. Kor. Soc. Groundwater Environ. 5, 177-191.

Yun, S. T., Koh, Y. K., Choi, H. S., Youm, S. J. and So, C. S. (1998b) Geochemistry of geothermal waters in Korea: environmental isotope and hydrochemical characteristics. II. Jungwon and Munkyeong areas. Econ. Environ. Geol. 31, 201-213. 